\title{
Emergence of Prochloraz-Resistant Populations of Calonectria pauciramosa and Calonectria polizzii in Ornamental Nurseries of Southern Italy
}

Vladimiro Guarnaccia, Dalia Aiello, and Giancarlo Polizzi, Dipartimento di Gestione dei Sistemi Agroalimentari e Ambientali-sez. Patologia vegetale, University of Catania, 95123 Catania, Italy; Giancarlo Perrone and Gaetano Stea, Istituto di Scienze delle Produzioni Alimentari (ISPA), 70126 Bari, Italy; and Alessandro Vitale, Dipartimento di Gestione dei Sistemi Agroalimentari e Ambientali-sez. Patologia vegetale, University of Catania

\begin{abstract}
Guarnaccia, V., Aiello, D., Polizzi, G., Perrone, G., Stea, G., and Vitale, A. 2014. Emergence of prochloraz-resistant populations of Calonectria pauciramosa and Calonectria polizzii in ornamental nurseries of southern Italy. Plant Dis. 98:344-350.

Management of Calonectria spp. infections in nurseries requires scheduled fungicide applications, particularly with methyl benzimidazole carbamates (MBCs) and sterol demethylation inhibitors (DMIs). Due to rising concerns about the occurrence of MBC resistance in different Calonectria populations and variability in prochloraz efficacy in controlling these pathogens, a detailed study on prochloraz sensitivity distributions of Calonectria isolates belonging to the Calonectria scoparia complex was carried out. In total, 105 isolates collected in two distinct periods (1993 to 1996 and 2005 to 2009) were analyzed for prochloraz sensitivity. Based on DNA sequencing and phylogenetic

analyses of $\beta$-tubulin, histone $\mathrm{H} 3$, and translation elongation factor- $1 \alpha$ gene sequences, 69 and 36 isolates were identified as C. pauciramosa and $C$. polizzii, respectively. The isolates collected more recently (group B) had a reduced prochloraz sensitivity, as indicated by greater values for the effective dose to reduce growth by $50 \%$ than those collected earlier (group A). The reduced sensitivity detected in vitro corresponded to partial loss of fungicide efficacy in controlling infections in red clover and feijoa under controlled and semi-field conditions, respectively. Frequent prochloraz application in nurseries for controlling Calonectria spp. infections is discouraged.
\end{abstract}

Calonectria spp. are fungal pathogens distributed worldwide which cause cutting rot, damping-off, root rot, crown rot, stem lesion, and leaf blight in several economically important crops $(11,13,31,40,48)$. They are non-host-specific polyphagous and polycyclic (11,32). In Australia, Brazil, and South Africa, Calonectria spp. cause extensive forest plantation losses $(3,11,15)$. In the United States, Mediterranean basin, and the United Kingdom, these pathogens are responsible for many diseases on a wide range of ornamental plants $(22,26,29,41,42,47,54,57)$. In Italy, mainly two species, Calonectria pauciramosa C.L. Schoch \& Crous and $C$. morganii Crous, Alfenas, \& M.J. Wingf. have been associated with a broad range of host plants belonging to Anacardiaceae, Arecaceae, Ericaceae, Fabaceae, Myrtaceae, Polygalaceae, Rhamnaceae, and Sapindaceae families, causing a wide variety of disease symptoms $(44,45,47,49,52,53,55,56,61,62,67,68)$. More recently, it has been reported that $C$. pauciramosa includes cryptic species belonging to the $C$. scoparia complex, and multigene phylogeny analysis has revealed the occurrence of $C$. polizzii L. Lombard, Crous \& M.J. Wingf. in Italy (30) and Tunisia (32).

Calonectria diseases in Italy represent a major limiting factor for the production of ornamental plants. Several efforts have been taken to manage these Calonectria spp. infections by using various control measures, including more biological and physical approaches $(64,65)$. Nevertheless, chemical control is the approach used most often to manage Calonectria diseases of containergrown plants. In the past, good results have been obtained by using methyl benzimidazole carbamates (MBCs) in controlling these diseases $(4,27,46)$. Unfortunately, a high frequency of $\mathrm{MBC}$ resistant isolates has been reported within the Italian populations of C. pauciramosa and C. morganii $(50,63)$. Due to rising concerns about the widespread pathogen resistance to MBCs, sterol deme-

Corresponding author: A. Vitale, E-mail: alevital@unict.it

Accepted for publication 16 September 2013.

http://dx.doi.org/10.1094/PDIS-04-13-0425-RE

(C) 2014 The American Phytopathological Society thylase inhibitors (DMIs) have become the most common alternative fungicide. Prochloraz (IUPAC name: $N$-propyl- $N$-[2-(2,4,6trichlorophenoxy)ethyl]imidazole-1-carboxamid), an imidazole member of the DMIs, has been used successfully worldwide against various plant pathogens $(17,21,28,60)$. This fungicide was introduced into Italy in the early 1990s. This compound, although with poor systemic activity and short-term effects (24), was effective in controlling Calonectria diseases in southern Italy when it was used on a large scale $(43,51)$, thus confirming previous data on its effectiveness $(8,33,37)$. Recent surveys in the same areas, however, revealed that prochloraz treatments produce variable disease control efficacy (1). These observations raised concerns regarding the possible emergence of resistant populations.

The overall aim of this study was to determine whether these pathogens have indeed developed resistance to the compound by analyzing two subsets of Calonectria isolates collected from 1993 to 1996 and from 2005 to 2009 . The specific objectives were to (i) characterize all Calonectria isolates, (ii) compare the in vitro sensitivity to prochloraz between two subsets of isolates, and (iii) determine prochloraz impact on infections on Trifolium pratense L. (red clover) and Feijoa sellowiana O. Berg (feijoa) by sensitive and reduced sensitivity Calonectria isolates.

\section{Materials and Methods}

Sampling time, host plant, and fungal isolates. In total, 105 single-conidial isolates of Calonectria spp. collected from 1993 to 2009 from six ornamental nurseries located in southern Italy (Sicily and Calabria) were used in this study. Three nurseries (numbers 1,3 , and 4) were located in Catania province (Praiola, Carrubba, and Grotte, respectively), two (numbers 2 and 5) in Messina province (Barcellona and Milazzo, respectively), and one at Lamezia in Catanzaro province (Calabria region). In nurseries 1, 3, and 4, prochloraz has been extensively used, with an average of four to six applications per season since 2000. These isolates were collected from different host plants and only separated according to the sampling time in two distinct periods: from 1993 to 1996 (group A: 51 isolates) and from 2005 to 2009 (group B: 54 isolates) (Table 1). These isolates were stored both in single McCartney bottles with bidistilled deionized water $(\times 3)$ and on a malt 
extract agar (MEA; Oxoid) slant $(\times 3)$ at $20^{\circ} \mathrm{C}$. They were revived by subculturing on carnation leaf agar (CLA; 16) for 7 days at $25^{\circ} \mathrm{C}$ at a 2-year interval, after which they were recovered from infected tissue for a new storage in culture collection under sterilized water and on a MEA slant (11). All used isolates were grown on MEA at $25 \pm 1{ }^{\circ} \mathrm{C}$ in darkness for 8 days. These colonies were employed for the morphological examination, molecular analysis, and conidial production for the inoculation of red clover and feijoa plants.

Molecular identification of Calonectria isolates by DNA sequence analysis. Species identification was carried out by DNA sequencing and phylogenetic analyses of $\beta$-tubulin (benA), histone $\mathrm{H} 3$ (HIS3), and translation elongation factor- $1 \alpha(T E F-1 \alpha)$ gene sequences. Each fungal strain was grown in liquid culture (150 $\mathrm{rpm}, 25^{\circ} \mathrm{C}, 2$ days) on Wickerham medium containing $40 \mathrm{~g}$ of glucose, $5 \mathrm{~g}$ of peptone, $3 \mathrm{~g}$ of yeast extract, and $3 \mathrm{~g}$ of malt extract in 1 liter of water. Subsequently, the mycelium was filtered and lyophilized for total DNA isolation. Fungal DNA was extracted with the Wizard Magnetic DNA purification Kit for food (Promega Corp.), with some modifications, including halving the volume of the reaction and starting from $10 \mathrm{mg}$ of lyophilized mycelium. The quality of genomic DNA was determined by agarose gel electrophoresis and quantification was carried out using the ND-1000 Spectrophotometer (Thermo Fisher Scientific). The primers T1 (39) and CYLTUB1R (12) were used for the amplification of part of benA, primers CYLH3F and CYLH3R (12) for HIS3, and pri- mers EF1-728F(7) and CylEF-R2 (12) for $T E F-1 \alpha$. Primer concentrations and polymerase chain reaction (PCR) program were the same as those used in the study by Vitale et al. (64).

Preliminary alignment of the three sequenced loci (benA, HIS3, and $T E F-1 \alpha$ ) was performed by using the software package BioNumerics (version 5.1; Applied Maths), and manual adjustment for improvement was made wherever necessary. Phylogenetic analysis was first conducted on the three single-locus alignments and, subsequently, the combined alignment of the three loci was analyzed for inferring organismal phylogeny. Multilocus alignment was performed using the Clustal W algorithm in MEGA version 5 (59). Phylogenetic and molecular evolutionary analyses were inferred by using the maximum likelihood method based on the Tamura-Nei model (58). The percentage of trees in which the associated taxa clustered together was shown next to the branches. The initial tree for the heuristic search was obtained automatically. When the number of common sites was less than 100 or one-fourth of the total number of sites, the maximum parsimony method was used; otherwise, the BIONJ method with maximum composite likelihood distance matrix was used. A discrete $\gamma$ distribution was used to model the evolutionary rate differences among the sites (five categories $[+G$ parameter $=2.1893])$. Evolutionary analyses were conducted in MEGA5. Maximum parsimony analysis was also performed for all datasets, branches of zero length were collapsed, and all multiple equally parsimonious trees were saved. The bootstrap (BP) consensus tree inferred from 1,000 replicates was con-

Table 1. Distribution of two subsets of Calonectria pauciramosa and C. polizzii isolates from different nurseries and host plants by their effective dose to reduce growth by $50 \%\left(\mathrm{EC}_{50}\right)$ of prochloraz

\begin{tabular}{|c|c|c|c|c|c|c|c|c|c|c|c|}
\hline \multirow[b]{2}{*}{ Host (nursery) } & \multirow[b]{2}{*}{ Calonectria spp. } & \multicolumn{5}{|c|}{ Group A (1993 to 1996) at $\mathrm{EC}_{50}$ range } & \multicolumn{5}{|c|}{ Group B (2005 to 2009) at $\mathrm{EC}_{50}$ range } \\
\hline & & 0-10 & 10-25 & $\mathbf{2 5 - 5 0}$ & 50-100 & Total $(n)$ & 0-10 & $10-25$ & $\mathbf{2 5 - 5 0}$ & $50-100$ & Total $(n)$ \\
\hline Arbutus unedo (1) & C. polizzii & & $\cdots$ & $\ldots$ & $\ldots$ & $\ldots$ & $\ldots$ & 2 & $\ldots$ & 1 & $\ldots$ \\
\hline Callistemon citrinus (1) & C. pauciramosa & 2 & 1 & $\ldots$ & $\ldots$ & $\ldots$ & $\ldots$ & $\ldots$ & $\ldots$ & $\ldots$ & $\ldots$ \\
\hline $\begin{array}{l}\text { Callistemon 'Masotti' (1) } \\
\text { Escallonia rubra (1) }\end{array}$ & $\begin{array}{l}\text { C. pauciramosa } \\
\text { C. pauciramosa, }\end{array}$ & $\cdots$ & $\cdots$ & $\cdots$ & $\cdots$ & $\cdots$ & $\cdots$ & $\cdots$ & 1 & $\cdots$ & $\cdots$ \\
\hline Feijoa sellowiana (1) & $\begin{array}{l}\text { C. polizzii } \\
\text { C. pauciramosa, }\end{array}$ & $\cdots$ & $\cdots$ & $\ldots$ & $\ldots$ & $\ldots$ & 1 & 1 & $\cdots$ & $\ldots$ & $\cdots$ \\
\hline & C. polizzii & $\ldots$ & $\ldots$ & $\cdots$ & $\ldots$ & 8 & 1 & 4 & 1 & 1 & 17 \\
\hline Melaleuca hypericifolia (1) & C. polizzii & $\ldots$ & $\ldots$ & 1 & $\ldots$ & $\ldots$ & $\ldots$ & $\ldots$ & $\ldots$ & $\cdots$ & $\cdots$ \\
\hline Myrtus communis (1) & $\begin{array}{l}\text { C. pauciramosa, } \\
\text { C. polizzii }\end{array}$ & 1 & $\ldots$ & $\ldots$ & 1 & $\ldots$ & 1 & 1 & 2 & $\ldots$ & $\ldots$ \\
\hline Polygala myrtifolia (1) & C. pauciramosa & 1 & $\ldots$ & 1 & $\ldots$ & $\ldots$ & $\ldots$ & $\ldots$ & $\cdots$ & $\ldots$ & $\ldots$ \\
\hline Callistemon citrinus (2) & C. polizzii & 1 & 1 & $\ldots$ & $\ldots$ & 4 & $\ldots$ & $\ldots$ & $\ldots$ & $\ldots$ & - \\
\hline Callistemon laevis (2) & C. pauciramosa, & & & & & & & & & & \\
\hline & C. polizzii & 2 & $\ldots$ & $\ldots$ & $\ldots$ & $\ldots$ & $\ldots$ & $\ldots$ & $\ldots$ & $\ldots$ & $\ldots$ \\
\hline Arbutus unedo (3) & C. polizzii & 2 & $\ldots$ & $\ldots$ & $\ldots$ & $\ldots$ & $\ldots$ & $\ldots$ & $\ldots$ & $\ldots$ & $\ldots$ \\
\hline Callistemon laevis (3) & C. pauciramosa & & 1 & $\ldots$ & $\ldots$ & $\ldots$ & $\ldots$ & $\ldots$ & $\ldots$ & $\ldots$ & $\ldots$ \\
\hline Callistemon 'Mauve Mist' (3) & C. pauciramosa, & & & & & & & & & & \\
\hline Ceanothus thyrsiflorus (3) & $\begin{array}{l}\text { C. polizzii } \\
\text { C. pauciramosa, }\end{array}$ & 4 & $\cdots$ & $\cdots$ & $\cdots$ & $\cdots$ & $\cdots$ & $\cdots$ & $\cdots$ & $\cdots$ & $\cdots$ \\
\hline Metrosideros robustus (3) & $\begin{array}{l}\text { C. polizzii } \\
\text { C. pauciramosa, }\end{array}$ & $\cdots$ & $\cdots$ & $\ldots$ & $\cdots$ & 12 & 10 & 1 & 1 & $\ldots$ & 19 \\
\hline Myrtus communis (3) & $\begin{array}{l}\text { C. polizzii } \\
\text { C. pauciramosa, }\end{array}$ & $\ldots$ & $\ldots$ & $\ldots$ & $\ldots$ & $\cdots$ & 2 & 2 & 2 & 1 & $\ldots$ \\
\hline & C. polizzii & 3 & 1 & $\ldots$ & $\ldots$ & $\cdots$ & $\ldots$ & $\ldots$ & $\ldots$ & $\ldots$ & $\ldots$ \\
\hline Polygala myrtifolia (3) & C. pauciramosa & & 1 & $\ldots$ & $\ldots$ & $\ldots$ & $\ldots$ & $\ldots$ & $\ldots$ & $\ldots$ & $\ldots$ \\
\hline Acacia retinodes (4) & $\begin{array}{l}\text { C. pauciramosa, } \\
\text { C. polizzii }\end{array}$ & 7 & 1 & 1 & & & & & & & \\
\hline Agonis flexuosa (4) & C. pauciramosa & $\ldots$ & $\ldots$ & $\ldots$ & $\ldots$ & $\ldots$ & 1 & $\ldots$ & $\ldots$ & 1 & $\ldots$ \\
\hline Brahea armata (4) & C. polizzii & $\ldots$ & $\ldots$ & $\ldots$ & $\ldots$ & $\ldots$ & 2 & 1 & $\ldots$ & $\ldots$ & $\ldots$ \\
\hline Callistemon laevis (4) & C. pauciramosa & $\ldots$ & $\ldots$ & $\ldots$ & $\ldots$ & $\ldots$ & 1 & $\ldots$ & $\ldots$ & $\ldots$ & $\ldots$ \\
\hline Eucalyptus rostrata (4) & C. polizzii & 1 & 1 & $\ldots$ & $\ldots$ & $\ldots$ & $\ldots$ & $\ldots$ & $\ldots$ & $\ldots$ & $\ldots$ \\
\hline Eugenia myrtifolia (4) & C. pauciramosa & $\ldots$ & $\ldots$ & $\cdots$ & $\ldots$ & 13 & 1 & 2 & $\ldots$ & $\ldots$ & 18 \\
\hline Feijoa sellowiana (4) & C. pauciramosa & $\ldots$ & $\ldots$ & $\ldots$ & $\ldots$ & $\ldots$ & $\ldots$ & 1 & $\ldots$ & $\ldots$ & $\ldots$ \\
\hline Melaleuca fulgens (4) & C. pauciramosa & $\ldots$ & $\ldots$ & $\ldots$ & $\ldots$ & $\ldots$ & $\ldots$ & 2 & $\ldots$ & $\ldots$ & $\ldots$ \\
\hline Metrosideros robustus (4) & C. pauciramosa & 1 & $\ldots$ & $\ldots$ & $\ldots$ & $\ldots$ & $\cdots$ & $\cdots$ & $\cdots$ & $\ldots$ & $\ldots$ \\
\hline Myrtus communis (4) & C. polizzii & 1 & $\ldots$ & $\ldots$ & $\ldots$ & $\ldots$ & $\ldots$ & $\ldots$ & $\ldots$ & $\ldots$ & $\ldots$ \\
\hline Pistacia lentiscus (4) & C. pauciramosa & $\ldots$ & $\ldots$ & $\ldots$ & $\ldots$ & $\ldots$ & 5 & 1 & $\ldots$ & $\ldots$ & $\ldots$ \\
\hline Callistemon viminalis (5) & C. pauciramosa & 7 & 3 & 0 & 1 & 11 & $\ldots$ & $\ldots$ & $\ldots$ & $\ldots$ & - \\
\hline Callistemon citrinus (6) & C. polizzii & $\ldots$ & 1 & $\ldots$ & $\ldots$ & 3 & $\ldots$ & $\ldots$ & $\ldots$ & $\ldots$ & $\ldots$ \\
\hline Polygala myrtifolia (6) & C. polizzii & 2 & $\ldots$ & $\ldots$ & $\ldots$ & $\ldots$ & $\ldots$ & $\ldots$ & $\ldots$ & $\ldots$ & - \\
\hline Total $(n)$ & $\ldots$ & 35 & 11 & 3 & 2 & 51 & 25 & 18 & 7 & 4 & 54 \\
\hline Relative frequency (\%) & $\ldots$ & 68.63 & 21.57 & 5.88 & 3.92 & 100 & 46.30 & 33.33 & 12.96 & 7.41 & 100 \\
\hline
\end{tabular}


sidered to represent the evolutionary history of the taxa analyzed. The maximum parsimony trees were obtained using the closeneighbor-interchange algorithm with search level 3 , in which the initial trees were obtained with the random addition of sequences (10 replicates). The trees were drawn to scale, with branch lengths calculated using the average pathway method, in the units of the number of changes over the whole sequence (38). All positions containing gaps and missing data were eliminated from the dataset (complete deletion option).

Determination of sensitivity to prochloraz of Calonectria isolates. The effects of prochloraz on the mycelial growth of all Calonectria isolates were tested in $90-\mathrm{mm}$ petri dishes containing potato dextrose agar (PDA; Oxoid) amended with the active ingredient (a.i.). For this purpose, a commercial formulation of prochloraz (462 $\mathrm{g} \mathrm{kg}^{-1}$; Octave; BASF Italia) was used and two a.i. stock solutions of $100 \mu \mathrm{g} \mathrm{ml}^{-1}$ were prepared in sterile distilled water (SDW). Autoclaved PDA was amended to make final concentrations of the a.i. of $0.5,5,10,20,50$, and $100 \mu \mathrm{g} / \mathrm{ml}$ of medium by adding appropriate volumes of the fungicide stock solutions. Nonamended PDA plates were used as controls. Mycelial plugs of Calonectria isolates were removed from the edge of the actively growing 5-day-old MEA colonies and placed upside down at the center of the amended and nonamended PDA plates. The cultures were incubated at $25^{\circ} \mathrm{C}$ in the dark for 5 days. This in vitro assay included three replicate plates per isolate and chemical concentration and was performed twice.

Radius of mycelial growth in individual plates was measured and the raw data from the three replicates were used to calculate growth reduction $(\mathrm{GR})=[1-($ radius in amended plates/radius of control plates) $] \times 100$. Dose-response curves for individual isolates were generated by plotting all GR values against $\log _{10}$ of the prochloraz concentration (Microsoft Excel 7.0), and the effective dose to reduce growth by $50 \%\left(\mathrm{EC}_{50}\right)$ was calculated using the regression equation generated through the linear portion of the sigmoid curve.

Effect of prochloraz on infection of red clover by Calonectria isolates. Growth chamber experiments were performed to determine the effect of prochloraz on Calonectria spp. infections of red clover ( $T$. pratense L.) seedlings, which have been used as a model host in recent studies $(64,65,69)$. Eight sensitive isolates and eight isolates with reduced sensitivity, selected on the basis of $\mathrm{EC}_{50}$ as determined above, were used in these experiments. Each isolate was subjected to two treatments: (i) prochloraz application at the label rate (100 g/100 liters) and (ii) nontreated control. Healthy red clover seed were surface disinfected for 2 min with $\mathrm{NaOCl}(1.2 \%$ [vol/vol]) and rinsed thrice in SDW. In all, 40 to 60 seeds were placed in an aluminum trays ( 9 by $11.5 \mathrm{~cm}$ ) containing sterile peat to allow proper germination. Three replicate trays were included in each of 16 treatments and these treatments were arranged in a randomized complete block design (RCBD).

Seven days after seeding, $6.5 \mathrm{ml}$ of conidial suspension at $1 \times$ $10^{5}$ conidia $\mathrm{ml}^{-1}$ was sprayed onto young red clover seedlings in each aluminum tray. The conidial suspensions were obtained from 7-day-old cultures grown on CLA plates (16) by adding about 10 $\mathrm{ml}$ of SDW to the plates and dislodging the conidia. Prochloraz was applied to the red clover seedlings by spraying $7 \mathrm{ml}$ of the solution for each replicate tray, $3 \mathrm{~h}$ before inoculation. Control seedlings were sprayed with SDW. All trays containing red clover seedlings were transferred and maintained in a growth chamber at $25^{\circ} \mathrm{C}$ under near-UV light with a regime of $16 \mathrm{~h}$ of light and $8 \mathrm{~h}$ of darkness at about $95 \%$ relative humidity. Disease evaluation was performed 7 days after inoculation. All dead red clover seedlings, including those showing typical Calonectria disease symptoms (crown and root rot, stem rot, and leaf spot) were counted, and the percentage of seedlings infected was calculated as disease incidence (DI). Prochloraz effect was measured by the DI reduction in the treated seedlings against those not treated. These experiments were conducted twice.

Effect of prochloraz on infections of feijoa by Calonectria isolates. Two sensitive Calonectria isolates and two with reduced sensitivity were used to further evaluate prochloraz efficacy in controlling infections of feijoa ( $F$. sellowiana $\mathrm{O}$. Berg) plants under semi-field conditions.

Four experiments were carried out by applying each isolate onto feijoa seedlings grown in containers $(8 \mathrm{~cm}$ in diameter). The experimental schemes included a control (seedlings inoculated only with a Calonectria isolate) and fungicide treatment (seedlings treated with prochloraz at $100 \mathrm{~g} \mathrm{hl}^{-1}$ and inoculated with a Calonectria isolate) for each isolate. In total, 720 healthy feijoa seedlings were used for pathogen inoculation and were arranged in RCBD with three replicates (30 seedlings per replicate) for each treatment. The fungicide and conidial suspensions were applied according to the methods reported for the previous assays but the fungicide applications were repeated at a 10-day interval and only collar and root portions were subjected to pathogen inoculation. Control feijoa seedlings were sprayed with SDW and inoculated with conidial suspension. The DI and symptom severity (SS) caused by Calonectria isolates were evaluated 40 days after inoculation. The SS of Calonectria spp. infections on the crown and root was assessed by the mean disease rating calculated using an empirical 1-to-5 rating scale that considers the percentage of infected crown and root area, where $1=$ no symptoms, $2=1$ to $10 \%$ infection, $3=11$ to $25 \%$ infection, $4=26$ to $50 \%$ infection, and 5 $=$ more than $50 \%$ of the surface being infected. Each experiment was conducted twice.

Statistical data analysis. All data obtained from the RCBD in each experiment were subjected to analysis of variance according to parametric or nonparametric approaches (Statistica 10; Statsoft Inc.) with factorial treatment structure and interactions. Both $\mathrm{EC}_{50}$ distributions were previously transformed in two nonlinear regressions fitting with Gaussian curves, and Pearson correlation coefficients were calculated. Subsequently, two normal distribution curves with estimated $\mu$ mean were compared by using a $\chi^{2}$ test to ascertain statistically significant difference. All percentage data were transformed using arcsine $\left(\sin ^{-1}\right.$ square root $x$ ) prior to statistical analysis. The untransformed means of red clover mortality (\%) ( \pm standard error of the mean), and DI of Calonectria spp. infections on feijoa are presented in the tables and separated by Fisher's least significant difference test $(P<0.05,0.01$, and 0.001). For the DI data that referred to Calonectria spp. infections on red clover, means were calculated for both sensitive and reduced-sensitivity groups of pathogen isolates to summarize the prochloraz efficacy in reducing Calonectria spp. infections within two subsets of isolates. Because an ordinal scale was adopted to evaluate Calonectria disease symptoms on feijoa plants, the SS data were analyzed according to nonparametric approaches. In other words, two-way analysis using the Friedman test and one-way analysis employing the Mann-Whitney test were used to evaluate fungicide-trial interactions and fungicide effects on SS reduction on feijoa plants, respectively. Furthermore, Kendall's coefficient of concordance $(W)$ was previously calculated to assess whether the rankings of the SS data were similar in each trial. Because $W$ was less than 0.75 with an associated low $\chi^{2}$ value for one isolate, the trials (first and second) were individually presented, calculating $Z$ according to the Mann-Whitney test and the associated $P$ level.

\section{Results}

Molecular identification of Calonectria isolates by DNA sequence analysis. Amplicons of benA, HIS3, and TEF-1 $\alpha$ were about 600,450 , and 500 bases, respectively, and no conflict in tree topology was observed for the three loci. However, only benA exhibited clear differentiation, with high BP between the closely related species $C$. polizzii and $C$. pauciramosa. The combined sequence dataset for benA, HIS3, and TEF-1 $\alpha$ consisted of 1,508 characters and, among them, 1,140 were constant and 367 were variable, of which 361 were parsimoniously informative. The evolutionary history was inferred by using the maximum likelihood method that resulted in a tree with the highest log likelihood $(-3,952.5559)$. The percentage of trees in which the associated taxa clustered together was shown next to the branches (BP analysis; 
Fig. 1). A discrete $\gamma$ distribution was used to model evolutionary rate differences among the sites (five categories $[+G$ parameter $=$ 2.1893]). The tree was drawn to scale, with branch lengths measured in the number of substitutions per site. The analysis involved 117 nucleotide sequences. The codon positions included were first + second + third + noncoding. All positions containing gaps and missing data were eliminated. There were 1,432 positions in the final dataset. In addition, the consensus tree obtained from maximum parsimony analysis confirmed the tree topology obtained with the maximum likelihood method as well as BP support. In particular, the evolutionary history was inferred using the maximum parsimony method. Out of 1,243 most parsimonious trees (length = 428), 1 tree was obtained. The consistency index was 0.9291 , retention index was 0.9719 , and composite index was

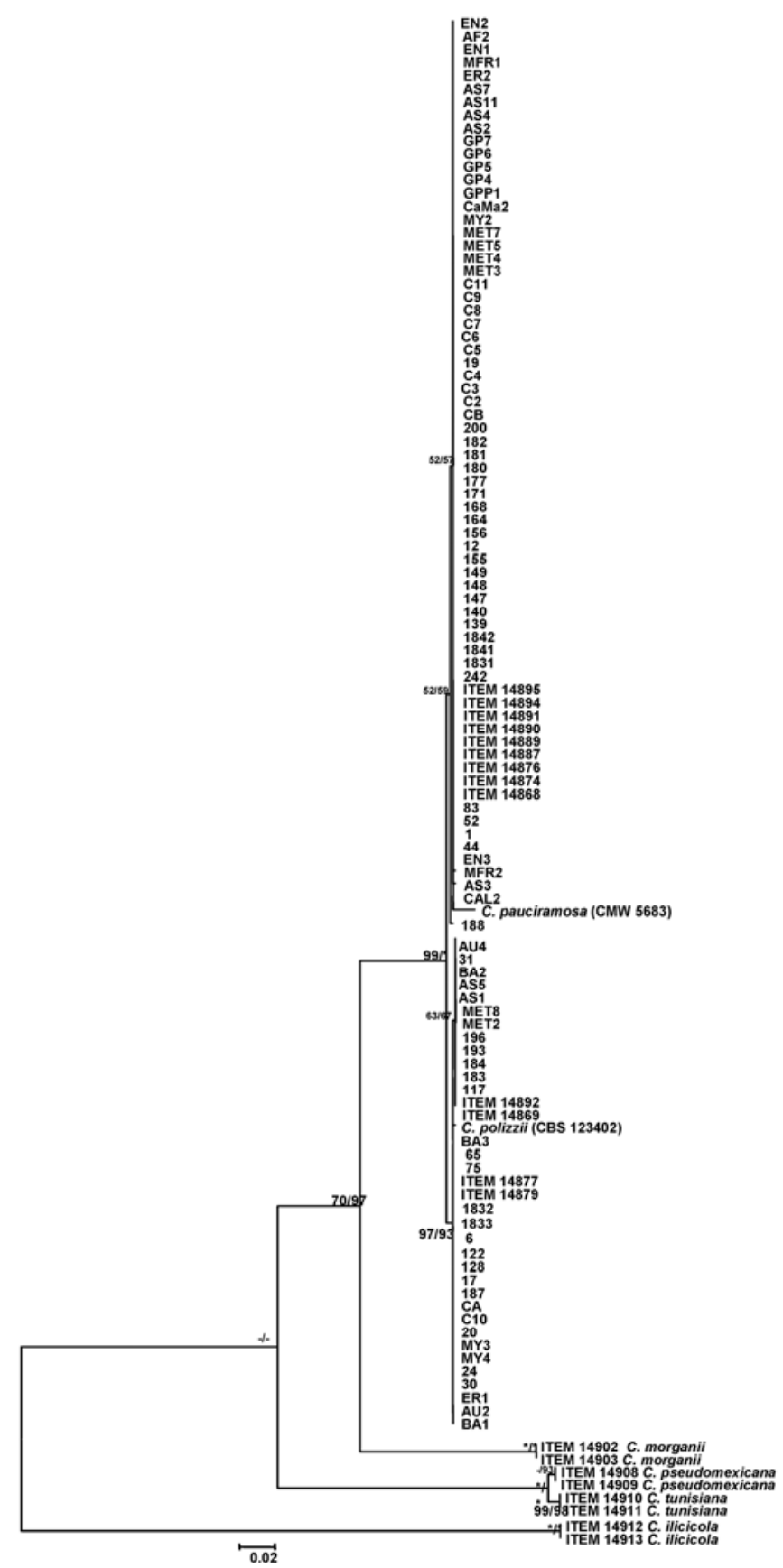

Fig. 1. Multilocus ( $\beta$-tubulin [benA], histone $\mathrm{H} 3$ [HIS3], and translation elongation factor-1 $\alpha[T E F-1 \alpha]$ ) phylogenetic tree by maximum likelihood (ML) method and maximum parsimony (MP) is represented. The tree with the highest likelihood $(-3,952.3559)$ and 1 of 1,243 most parsimonious trees is shown. Numbers above branches are bootstrap values of ML and MP analysis, respectively. Only values above $50 \%$ are indicated; ${ }^{*}=100 \%$ and $-<50 \%$ of the bootstrap value.
0.9038 (0.9030) for all sites and parsimoniously-informative sites (in parentheses). The three-loci dataset phylogenetic analysis showed a monophyletic group for $C$. polizzii strains with a BP value of $97 \%$ (Fig. 1) and less than $70 \%$ for C. pauciramosa (59 and $52 \%$ for maximum parsimony and maximum likelihood method, respectively). The cluster of these two sister species exhibited high BP values in both analyses (maximum parsimony and maximum likelihood methods) with respect to the other closely related species of the group (Fig. 1).

Determination of prochloraz sensitivity of Calonectria isolates. Growth reduction of the Calonectria isolates of both groups $\mathrm{A}$ and $\mathrm{B}$ increased with increasing prochloraz concentration from 0.5 to $100 \mu \mathrm{g} \mathrm{ml}^{-1}$. Indeed, all treatments exhibited a decrease in fungal growth, and the decrease was significantly different after 5 days of incubation (data not shown).

Isolates collected between1993 and 1996 (group A) were more sensitive to prochloraz than those collected between 2005 and 2009 (group $\mathrm{B}$ ). The $\mathrm{EC}_{50}$ values ranged from less than 0.001 to 79.80 $\mu \mathrm{g} \mathrm{ml}^{-1}$ (arithmetic mean $=12.54 \mu \mathrm{g} \mathrm{ml}^{-1}$ ) for the 51 group A isolates and from 0.14 to $91.77 \mu \mathrm{g} \mathrm{ml}^{-1}$ (arithmetic mean $=16.97 \mu \mathrm{g}$ $\mathrm{ml}^{-1}$ ) for the 54 group B isolates (Table 1). The majority of the group $\mathrm{B}$ isolates had $\mathrm{EC}_{50}$ values between 10 and $100 \mu \mathrm{g} \mathrm{ml}^{-1}$, whereas most group A isolates had $\mathrm{EC}_{50}$ values of less than $10 \mu \mathrm{g}$ $\mathrm{ml}^{-1}$ (Table 1). The estimated single $\mathrm{EC}_{50}$ value with high frequency according to normal distribution was different between the two groups (i.e., falling within 5 to $10 \mu \mathrm{g} \mathrm{ml}^{-1}\left[7.02 \mu \mathrm{g} \mathrm{m}{ }^{-1}\right]$ for the isolates of group A and within 10 to $25 \mu \mathrm{g} \mathrm{ml}^{-1}\left[13.38 \mu \mathrm{g} \mathrm{ml}^{-1}\right.$ ] for the isolates of group B) (Fig. 2). The $\mathrm{EC}_{50}$ distributions for both the groups fitted well two nonlinear regression curves according to Gaussian (normal) distribution with a good approximation (Pearson correlation coefficient $[R]$; Fig. 2). Statistical analysis between the two Gaussian curves with relative estimated $\mu$ (= mean, median, and mode for normal distribution) showed a significant difference $(P<0.05)$ according to $\chi^{2}$ test (Fig. 2). A similar distribution of $\mathrm{EC}_{50}$ to prochloraz was maintained for 69 C. pauciramosa and $36 C$. polizzii isolates, separately analyzed. $\mathrm{The}^{\mathrm{E}} \mathrm{C}_{50}$ distribution to prochloraz within a single group was related only to monitoring time and the shift in reduced sensitivity to prochloraz $(>10$ $\mu \mathrm{g} \mathrm{ml}^{-1}$ ) within two groups was similar for C. pauciramosa and $C$. polizzii isolates (data not shown). Both single C. pauciramosa and C. polizzii isolates were grouped as isolates with reduced sensitivity $\left(>10 \mu \mathrm{g} \mathrm{ml}^{-1}\right)$ to prochloraz (RS) and isolates sensitive $(<10 \mu \mathrm{g}$ $\mathrm{ml}^{-1}$ ) to prochloraz $(\mathrm{S})$.

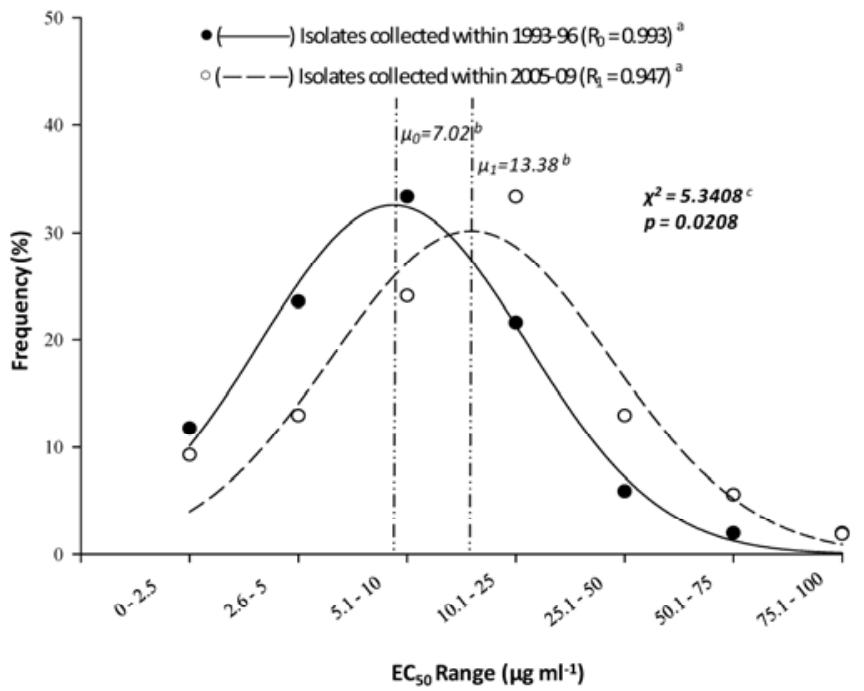

Fig. 2. Gaussian distribution of Calonectria isolates collected during 1993 to 1996 and 2005 to 2009 in Italy by their effective dose to reduce growth by $50 \%\left(E_{50}\right)$ value of prochloraz sensitivity. (a) $R_{0}$ and $R_{1}=$ Pearson correlation coefficients in two nonlinear regression curves calculated for two subsets of isolates; (b) $\mu_{0}$ and $\mu_{1}=$ estimated means for two subsets of isolates; (c) $\chi^{2}$ and associated $P$ value denote significant difference between two examined distributions. 
Effect of prochloraz on infection of red clover by Calonectria isolates. Regardless of prochloraz sensitivity, all isolates caused disease symptoms on red clover seedlings. Because no significant treatment-assay interaction on Calonectria spp. infection was detected, the data from two repeating experiments were pooled in statistical analysis (Table 2). On average, prochloraz reduced $68 \%$ of infection of red clover seedlings caused by $\mathrm{S}$ isolates but only $23 \%$ of that by RS isolates (Table 2). Overall, prochloraz significantly reduced the disease caused by all $\mathrm{S}$ isolates without exception, regardless of species. In contrast, it suppressed the disease caused by only four of the eight RS isolates (Table 2).

Effect of prochloraz on infections of feijoa by Calonectria isolates. Both $\mathrm{S}$ and RS isolates caused severe infections under the semi-field conditions. Because a significant treatment-trial interaction was detected for one of the four isolates, data obtained from an individual trial were presented separately (Table 3). Substantially reduced control of Calonectria spp. infections was consistently observed on seedling inoculated with RS isolates compared with those with $\mathrm{S}$ isolates.

\section{Discussion}

Reduced sensitivity or even field resistance of several plant pathogens to prochloraz are reported in literature $(20,25,34,36)$. However, this article provides the first data on occurrence of prochloraz-resistance in Calonectria populations.

Our molecular data allowed us to recognize within the subset of Calonectria spp. isolates two species (i.e., C. pauciramosa and $C$. polizzii) according to the findings of a more recent article by Vitale et al. (64), thus demonstrating that $C$. polizzii is well established in southern Italy. Therefore, this species, recently described (30) and regarded as sporadically occurring in Sicilian nurseries (1), should be considered with $C$. pauciramosa and $C$. morganii to be responsible for heavy losses in ornamental plant production in Sicily.

This article helps explain the variations in field efficacy of prochloraz against Calonectria diseases in Italy since the mid-2000s $(1,51,66)$, and worldwide $(5,8,23,33,37)$. Calonectria populations in nurseries of Southern Italy have altered toward resistance to prochloraz. This shift in sensitivity to prochloraz between two subsets of Calonectria isolates collected in 1993 to 1996 and 2005 to 2009 may be due to the extensive use of this fungicide in the nurseries. The sensitivity to prochloraz was very similar for both $C$. pauciramosa and C. polizzii.

As has happened for other pathogens with DMI fungicides, the resistance to prochloraz is difficult to demonstrate within
Calonectria populations because it requires long monitoring periods $(9,18)$. For compounds belonging to this group, decrease in prochloraz sensitivity within pathogen populations has gradually developed because of the quantitative nature of resistance that is related to two or more genes $(6,14)$. This behavior is different from that of MBC compounds, which have selected fungicide-resistant isolates of Calonectria spp. within very brief periods after their use in Italy $(2,19,50,63)$. However, as decrease in prochloraz-sensitivity within Calonectria populations occurs, prochloraz may not be able to provide an adequate control of Calonectria spp. infections, as confirmed by our in vivo experiments. Therefore, the emergence of resistant populations could result in heavy losses in ornamental production which can occur more frequently if prochloraz is ap-

Table 3. Differential prochloraz effect on crown and root rot of feijoa caused by sensitive and reduced sensitivity Calonectria isolates in semifield conditions ${ }^{\mathrm{y}}$

\begin{tabular}{|c|c|c|c|c|}
\hline \multirow[b]{2}{*}{ Isolates, treatment } & \multicolumn{2}{|c|}{ First trial } & \multicolumn{2}{|c|}{ Second trial } \\
\hline & DI $(\%)^{\mathrm{z}}$ & SS & DI (\%) & SS \\
\hline \multicolumn{5}{|l|}{ Sensitive } \\
\hline \multicolumn{5}{|c|}{$\begin{array}{l}\text { Calonectria pauciramosa } \\
14894\end{array}$} \\
\hline Control & $73.33 \mathrm{a}$ & $1.94 \mathrm{a}$ & $77.78 \mathrm{a}$ & $2.29 \mathrm{a}$ \\
\hline Prochloraz & $21.10 \mathrm{~b}$ & $0.27 \mathrm{~b}$ & $27.78 \mathrm{~b}$ & $0.31 \mathrm{~b}$ \\
\hline Reduction (\%) & 71.23 & 86.08 & 64.28 & 86.46 \\
\hline \multicolumn{5}{|l|}{ C. polizzii 14879} \\
\hline Control & $72.19 \mathrm{a}$ & $1.97 \mathrm{a}$ & $75.56 \mathrm{a}$ & $2.24 \mathrm{a}$ \\
\hline Prochloraz & $25.53 \mathrm{~b}$ & $0.34 \mathrm{~b}$ & $31.11 \mathrm{~b}$ & $0.41 \mathrm{~b}$ \\
\hline Reduction (\%) & 64.63 & 82.74 & 58.83 & 81.70 \\
\hline \multicolumn{5}{|l|}{ Reduced sensitivity } \\
\hline \multicolumn{5}{|c|}{ C. pauciramosa 14889} \\
\hline Control & $78.88 \mathrm{a}$ & $2.03 \mathrm{a}$ & $78.89 \mathrm{a}$ & $2.37 \mathrm{a}$ \\
\hline Prochloraz & $62.22 \mathrm{a}$ & $1.84 \mathrm{a}$ & $71.11 \mathrm{~b}$ & $1.44 \mathrm{~b}$ \\
\hline Reduction (\%) & 21.12 & 9.36 & 9.86 & 39.24 \\
\hline \multicolumn{5}{|c|}{ C. pauciramosa 14887} \\
\hline Control & $80.00 \mathrm{a}$ & $2.37 \mathrm{a}$ & $75.56 \mathrm{a}$ & $2.31 \mathrm{a}$ \\
\hline Prochloraz & $55.51 \mathrm{~b}$ & $1.23 \mathrm{~b}$ & $58.89 \mathrm{~b}$ & $1.67 \mathrm{~b}$ \\
\hline Reduction (\%) & 30.61 & 48.10 & 22.06 & 27.71 \\
\hline
\end{tabular}

y DI = disease incidence and SS = severity symptoms. Data are the means of three replicates each having 32 young feijoa plants. Values followed by the same letter within a column are not significantly different according to the Fisher's least significance difference test $(P=0.01)$ for DI and the Mann-Whitney test for SS $(P<0.05)$. Arcsine square root transformation was applied on percentage prior to data analysis.

${ }^{\mathrm{z}}$ Control $=$ untreated, inoculated seedlings.

Table 2. Differential prochloraz effect on infection caused by sensitive and reduced sensitivity Calonectria isolates in growth chamber as measured by percentage of red clover seedlings infected

\begin{tabular}{|c|c|c|c|c|}
\hline Isolates & Nontreated $^{\mathbf{y}}$ & Treated $^{\mathrm{y}}$ & Reduction (\%) & $F$ test $(P)(\operatorname{Trtm})^{\mathrm{z}}$ \\
\hline \multicolumn{5}{|l|}{ Sensitive (S) } \\
\hline Calonectria polizzii 31 & $92.21 \pm 1.72$ & $29.42 \pm 6.59$ & 68.09 & $155.72 * *$ \\
\hline C. polizzii 14879 & $71.21 \pm 4.17$ & $23.72 \pm 3.35$ & 66.69 & $118.52 * *$ \\
\hline C. pauciramosa 188 & $53.88 \pm 7.78$ & $13.46 \pm 2.95$ & 75.02 & $29.95^{* *}$ \\
\hline C. polizzii 193 & $61.59 \pm 3.14$ & $19.23 \pm 4.21$ & 68.78 & $79.72 * *$ \\
\hline C. pauciramosa $\mathrm{EN} 3$ & $60.14 \pm 3.82$ & $37.39 \pm 3.85$ & 37.83 & $34.02 * *$ \\
\hline C. pauciramosa $\mathrm{Cal} 2$ & $79.15 \pm 3.65$ & $21.42 \pm 3.39$ & 72.94 & $162.79 * *$ \\
\hline C. pauciramosa 14894 & $68.30 \pm 8.35$ & $18.26 \pm 4.15$ & 73.26 & $44.50 * *$ \\
\hline C. paисіramosa 14895 & $51.77 \pm 11.73$ & $8.51 \pm 1.61$ & 83.56 & $31.75^{* *}$ \\
\hline Mean & $67.28 \pm 4.79$ & $21.43 \pm 3.19$ & 68.15 & $52.26^{* *} *$ \\
\hline \multicolumn{5}{|l|}{ Reduced sensitivity (RS) } \\
\hline C. pauciramosa 1 & $57.14 \pm 3.61$ & $50.49 \pm 3.00$ & 11.64 & $3.49^{\mathrm{ns}}$ \\
\hline C. polizzii 75 & $78.96 \pm 8.40$ & $57.92 \pm 6.12$ & 26.61 & $4.96^{\mathrm{ns}}$ \\
\hline C. polizzii 104 & $70.48 \pm 5.68$ & $53.97 \pm 5.63$ & 23.42 & $7.32^{\text {ns }}$ \\
\hline C. polizzii 187 & $100.0 \pm 0.00$ & $89.23 \pm 6.20$ & 10.67 & $7.06^{\mathrm{ns}}$ \\
\hline C. pauciramosa 14887 & $70.68 \pm 2.85$ & $43.80 \pm 4.36$ & 38.52 & $49.21 * *$ \\
\hline C. pauciramosa 14889 & $82.53 \pm 5.79$ & $61.94 \pm 3.85$ & 24.95 & $17.36^{*}$ \\
\hline C. pauciramosa 14891 & $73.70 \pm 2.50$ & $55.64 \pm 4.48$ & 24.50 & $19.51 *$ \\
\hline C. polizzii 14892 & $94.04 \pm 1.19$ & $69.62 \pm 2.96$ & 25.97 & $76.59 * *$ \\
\hline Mean & $78.44 \pm 4.86$ & $60.33 \pm 4.93$ & 23.09 & $5.63^{\text {ns }}$ \\
\hline
\end{tabular}

${ }^{y}$ Means \pm standard error of the mean) of 3 replicates each having 30 to 50 red clover seedlings.

${ }^{\mathrm{z}}$ Asterisks denote significant differences: $*$ and $* *$ indicate $P \leq 0.01$ and 0.001 , respectively, according to the Fisher's least significance difference test; ns $=$ not significant. 
plied alone. The lack of prochloraz efficacy in controlling Calonectria diseases could be avoided by increasing the fungicide rate $(6,14)$, because a small shift in reduced sensitivity to prochloraz over time was detected in this study. Nevertheless, dosages of prochloraz, which has recently gained European Union reregistration (10), are carefully regulated and, for outdoor applications, should not exceed $450 \mathrm{~g} \mathrm{ha}^{-1}$.

The present study shows that the sensitivity of C. pauciramosa and $C$. polizzii isolates to prochloraz can diminish over time. Based on these findings indicating a highly variable $\mathrm{EC}_{50}$ between sensitive and reduced-sensitivity isolates, frequent use of prochloraz to control Calonectria diseases is strongly discouraged. Currently, other fungicides with different modes of action are available for chemical management of Calonectria spp. infections in ornamental nurseries (1). For example, antiresistance strategies could include the use of copper compounds, phosphonate, and quinone outsideinhibitor fungicides that showed good activity in controlling Calonectria diseases (1). Because application of prochloraz for the control of other pathogens can result in a weaker selection in fungicide resistance to other DMIs (35), further studies on the sensitivity of Calonectria isolates to other DMIs should be carried out.

\section{Acknowledgments}

This research was supported by MIUR (project number PON01_01611). We thank F. Epifani for his valuable technical help in DNA extraction and sequencing of the strains, and A. Cinquerrui and P. T. Formica for their technical assistance in experimental assays.

\section{Literature Cited}

1. Aiello, D., Cirvilleri, G., Polizzi, G., and Vitale, A. 2013. Effects of fungicides treatments for the control of epidemic and exotic Calonectria diseases in Italy. Plant Dis. 97:37-43.

2. Alfenas, A., Demuner, N. L., and Da Silva, A. R. 1988. Benomyl resistant strain of Cylindrocladium scoparium, causal agent of cutting rot of Eucalyptus grandis in Brazil. ISPP Chem. Control Newsl. 10:23-25.

3. Alfenas, A. C., Matsuoka, K., Ferreira, F. A., and Hodges, C. S. 1979. Identificação, caracteristicas culturais e patogenicidade de três espécies de $C y l$ indrocladium isoladas de mancha de Eucalyptus spp. Fitopatol. Brasil. 4:445-459. (In Portuguese)

4. Barnard, E. L. 1984. Occurrence, impact, and fungicide control of girdling stem cankers caused by Cylindrocladium scoparium on Eucalyptus seedlings in a south Florida nursery. Plant Dis. 68:471-473.

5. Brand, T. 2006. In vitro activity of fungicidal compounds towards conidial germination and mycelial growth of Cylindrocladium buxicola. Nachrichtenbl. Dtsch. Pflanzenschutzdienst (Berlin) 58:117-121.

6. Brent, K. J., and Hollomon, D. W. 2007. Fungicide resistance: The assessment of risk. FRAC Monogr. No. 2, 2nd (revised) ed.

7. Carbone, I., and Kohn, L. M. 1999. A method for designing primer sets for speciation studies in filamentous ascomycetes. Mycologia 91:553-556.

8. Chase, A. R. 1985. Cylindrocladium root and petiole rot control update. Proc. Fla. State Hortic. Soc. 98:115-118

9. Clark, W. S. 1992. Practical aspects of resistance to DMI fungicides in barley powdery mildew Erysiphe graminis. Proc. Br. Crop. Prot. Conf. 177182.

10. Commission Implementing Regulation (EU) No. 1143/2011. 2011. Off. J. Eur. Union.

11. Crous, P. W. 2002. Taxonomy and pathology of Cylindrocladium (Calonectria) and allied genera. American Phytopathological Society, St. Paul, $\mathrm{MN}$.

12. Crous, P. W., Groenewald, J. Z., Risède, J. M., Simoneau, P., and HywelJones, N. 2004. Calonectria species and their Cylindrocladium anamorphs: species with sphaeropedunculate vesicles. Stud. Mycol. 50:415-430.

13. Crous, P. W., and Wingfield, M. J. 1994. A monograph of Cylindrocladium, including anamorphs of Calonectria. Mycotaxon 51:341-435.

14. Dekker, J. 1986. Preventing and managing fungicide resistance. Pages 347354 in: Fungicide Resistance: Strategies and Tactics for Management. National Academy Press, Washington, DC.

15. Ferreira, F. A., Alfenas, A. C., Moreira, A. M., and Demuner, N. L. 1995. Mancha-de-pteridis: Doença foliar de eucalipto em àreas tropicais brasileiras. Fitopatol. Brasil. 20:107-110. (In Portuguese)

16. Fisher, N. L., Burgess, L. W., Toussoun, T. A., and Nelson, P. E. 1982. Carnation leaves as a substrate and for preserving cultures of Fusarium species. Phytopathology 72:151-153.

17. Fletcher, J. T., Hims, M. J., and Hall, R. J. 1983. The control of bubble diseases and cobweb disease of mushrooms with prochloraz. Plant Pathol. 32:123-131.

18. Fletcher, J. T., and Wolfe, M. S. 1981. Insensitivity of Erysiphe graminis $\mathrm{f}$. sp. hordei to triadimefon, triadimenol and other fungicides. Proc. Br. Crop. Prot. Conf. 633-640.
19. French, D. W., and Menge, J. A. 1978. Survival of Cylindrocladium florida num in naturally and artificially infested forest tree nurseries. Plant Dis. Rep. 62:806-810.

20. Gea, F. J., Navarro, M. J., and Tello, J. C. 2005. Reduced sensitivity of the mushroom pathogen Verticillium fungicola to prochloraz-manganese in vitro. Mycol. Res. 109:741-745.

21. Gea, F. J., Tello, J. C., and Navarro, M. J. 2010. Efficacy and effects on yield of different fungicides for control of wet bubble disease of mushroom caused by the mycoparasite Mycogone perniciosa. Crop Prot. 29:10211025 .

22. Henricot, B., and Beales, P. 2003. First record of Cylindrocladium pauciramosum on myrtle (Myrtus communis L.) in Portugal. Plant Pathol. 52:420.

23. Henricot, B., Gorton, C., Denton, G., and Denton, J. 2008. Studies on the control of Cylindrocladium buxicola using fungicides and host resistance. Plant Dis. 92:1273-1279.

24. Jorgensen, L. N. 1991. Septoria spp.-use of different dosages and timing for optimal control. Tidsskr. Planteavl 85:159-171.

25. King, A. C., Cole, A. L. J., and Sanderson, F. R. 1986. Prochloraz insensitivity in isolates of the cereal eyespot fungus, Pseudocercosporella herpotrichoides, in New Zealand. Australas. Plant Pathol. 15:22-23.

26. Koike, S. T., Henderson, D. M., Crous, P. W., Schoch, C. L., and Tjosvold, S. A. 1999. A new root and crown rot disease of heath in California caused by Cylindrocladium pauciramosum. Plant Dis. 83:589.

27. Kucharek, T. A., and Atkins, J. 1993. Occurrence and control of Cylindrocladium black rot in peanuts in Florida. Soil Crop. Sci. Soc. Fla. Proc. 52:17-20.

28. Kurt, S., Dervis, S., and Sahinler, S. 2003. Sensitivity of Verticillium dahliae to prochloraz and prochloraz-manganese complex and control of Verticillium wilt of cotton in the field. Crop Prot. 22:51-55.

29. Lane, C. R., Beales, P. A., Henricot, B., and Holden, A. 2006. First record of Cylindrocladium pauciramosum on Ceanothus in the UK. Plant Pathol. $55: 582$

30. Lombard, L., Crous, P. W., Wingfield, B. D., and Wingfield, M. J. 2010. Multigene phylogeny and mating tests reveal three cryptic species related to Calonectria pauciramosa. Stud. Mycol. 66:15-30.

31. Lombard, L., Crous, P. W., Wingfield, B. D., and Wingfield, M. J. 2010 Species concepts in Calonectria (Cylindrocladium). Stud. Mycol. 66:1-14.

32. Lombard, L., Polizzi, G., Guarnaccia, V., Vitale, A., and Crous, P. W. 2011 Calonectria spp. causing leaf spot, crown and root rot of ornamental plants in Tunisia. Persoonia 27:73-79.

33. Lutz, A., Paulus, A. O., Ferrin, D. M., and Nelson, J. A. 1988. A new disease of myrtle. Calif. Agric. 42:24-25.

34. Mavroeidi, V. I., and Shaw, M. W. 2005. Sensitivity distributions and crossresistance patterns of Mycosphaerella graminicola to fluquinconazole, prochloraz and azoxystrobin over a period of 9 years. Crop Prot. 24:259-266.

35. Metcalfe, R. J., Shaw, M. W., Russell, P. E. 2000. The effect of dose and mobility on the strength of selection for DMI fungicide resistance in inoculated field experiments. Plant Pathol. 49:546-557.

36. Mwang'ombe, A. W. 1994. Tolerance in isolates of Colletotrichum coffeanum to prochloraz-Mn in Kenya. J. Phytopathol. 140:114-122.

37. Nan, Z. B., Long, P. G., and Skipp, R. A. 1992. Use of prochloraz and benomyl drenches to assess the effects of fungal root pathogens on growth of red clover under field conditions. Australas. Plant Pathol. 21:98-103.

38. Nei, M., and Kumar, S. 2000. Molecular Evolution and Phylogenetics. Oxford University Press, New York

39. O'Donnell, K., and Cigelnik, E. 1997. Two divergent intragenomic rDNA ITS2 types within a monophyletic lineage of the fungus Fusarium are nonorthologous. Mol. Phylogenet. Evol. 7:103-116.

40. Peerally, A. 1991. The classification and phytopathology of Cylindrocladium species. Mycotaxon 40:323-366.

41. Pérez-Sierra, A., Álvarez, L. A., Henricot, B., Garcìa-Jimènez, J., and Armengol, J. 2006. Cylindrocladium pauciramosum causes root and collar rot of Polygala myrtifolia in Spain. Plant Pathol. 55:298.

42. Pérez-Sierra, A., Álvarez, L. A., Leòn, M., Abad-Campos, P., Henricot, B. Armengol, J., and Garcìa-Jimènez, J. 2007. First report of leaf spot, blight, and stem lesions caused by Cylindrocladium pauciramosum on Callistemon in Spain. Plant Dis. 91:1057.

43. Polizzi, G. 2000. Prime esperienze di lotta chimica nei confronti del marciume del colletto e delle radici di Polygala myrtifolia causato da Cylindro cladium pauciramosum. Inf. Fitopatol. 11:39-47. (In Italian)

44. Polizzi, G., Aiello, D., Castello, I., Parlavecchio, G., Vitale, A., and Nigro, F. 2009. First report of crown rot caused by Cylindrocladium pauciramosum on scarlet honey myrtle in Italy. Plant Dis. 93:1217.

45. Polizzi, G., Aiello, D., Guarnaccia, V., Parlavecchio, G., and Vitale, A. 2009. First report of leaf spot and shoot blight caused by Cylindrocladium scoparium on mallee honey myrtle in Italy. Plant Dis. 93:1078.

46. Polizzi, G., and Azzaro, A. 1996. A new leaf spot disease of myrtle by Cylindrocladium scoparium and its control in nursery. Petria 6:117-123.

47. Polizzi, G., and Catara, V. 2001. First report of leaf spot caused by Cylindrocladium pauciramosum on Acacia retinodes, Arbutus unedo, Feijoa sellowiana, and Dodonaea viscosa in southern Italy. Plant Dis. 85:803.

48. Polizzi, G., and Crous, P. W. 1999. Root and collar rot of milkwort caused by Cylindrocladium pauciramosum, a new record for Europe. Eur. J. Plant Pathol. 105:413-415. 
49. Polizzi, G., Grasso, F. M., Vitale, A., and Aiello, D. 2007. First occurrence of Calonectria leaf spot on Mexican blue palm in Italy. Plant Dis. 91:1052.

50. Polizzi, G., and Vitale, A. 2001. First report of the prevalence of benzimidazole-resistant isolates in a population of Cylindrocladium pauciramosum in Italy. Plant Dis. 85:1210.

51. Polizzi, G., and Vitale, A. 2002. Biological control of Cylindrocladium root and collar rot of the myrtle-leaf milkwort by Trichoderma harzianum strain T-22. Biol. Cult. Tests Rep. 17:O14

52. Polizzi, G., Vitale, A., Aiello, D., Castello, I., Guarnaccia, V., and Parlavecchio, G. 2009. First record of crown and root rot caused by Cylindrocladium pauciramosum on brush cherry in Italy. Plant Dis. 93:547.

53. Polizzi, G., Vitale, A., Aiello, D., Dimartino, M. A., and Parlavecchio, G. 2007. First report of damping-off and leaf spot caused by Cylindrocladium scoparium on different accessions of bottlebrush cuttings in Italy. Plant Dis. 91:769.

54. Polizzi, G., Vitale, A., Aiello, D., Guarnaccia, V., Crous, P. W., and Lombard, L. 2012. First report of Calonectria ilicicola causing a new disease on Laurus (Laurus nobilis) in Europe. J. Phytopathol. 160:41-44.

55. Polizzi, G., Vitale, A., Aiello, D., and Parlavecchio, G. 2006. First record of crown and root rot caused by Cylindrocladium pauciramosum on California lilac in Italy. Plant Dis. 90:1459.

56. Polizzi, G., Vitale, A., Castello, I., Groenewald, J. Z., and Crous, P. W. 2006. Cylindrocladium leaf spot, blight, and crown rot, new diseases of mastic tree seedlings caused by Cylindrocladium scoparium. Plant Dis. 90:1110.

57. Schoch, C. L., Crous, P. W., Polizzi, G., and Koike, S. T. 2001. Female fertility and single nucleotide polymorphism comparisons in Cylindrocladium pauciramosum. Plant Dis. 85:941-946.

58. Tamura, K., and Nei, M. 1993. Estimation of the number of nucleotide substitutions in the control region of mitochondrial DNA in humans and chimpanzees. Mol. Biol. Evol. 10:512-526.

59. Tamura, K., Peterson, D., Peterson, N., Stecher, G., Nei, M., and Kumar, S. 2011. MEGA5: molecular evolutionary genetics analysis using maximum likelihood, evolutionary distance, and maximum parsimony methods. Mol. Biol. Evol. 28:2731-2739.

60. Vinggaard, A. M., Hass, U., Dalgaard, M., Andersen, H. R., BonefeldJørgensen, E., Christiansen, S., Laier, P., and Poulsen, M. E. 2006. Prochloraz: an imidazole fungicide with multiple mechanisms of action. Int J. Androl. 29:186-192.

61. Vitale, A., Aiello, D., Castello, I., Dimartino, M. A., Parlavecchio, G., and Polizzi, G. 2009. Severe outbreak of crown rot and root rot caused by Cylin drocladium pauciramosum on strawberry tree in Italy. Plant Dis. 93:842.

62. Vitale, A., Aiello, D., Castello, I., Parlavecchio, G., and Polizzi, G. 2008. First report of crown rot and root rot caused by Cylindrocladium pauci ramosum on Feijoa (Feijoa sellowiana) in Italy. Plant Dis. 92:1590.

63. Vitale, A., Aiello, D., Castello, I., and Polizzi, G. 2009. First report of benzimidazole-resistant isolates of Cylindrocladium scoparium in Europe. Plant Dis. 93:110.

64. Vitale, A., Castello, I., D’Emilio, A., Mazzarella, R., Perrone, G., Epifani, F., and Polizzi, G. 2013. Short-term effects of soil solarization in suppress ing Calonectria microsclerotia. Plant Soil 368:603-617.

65. Vitale, A., Cirvilleri, G., Castello, I., Aiello, D., and Polizzi, G. 2012. Evaluation of Trichoderma harzianum strain T22 as biological control agent of Calonectria pauciramosa. Biocontrol 57:687-696.

66. Vitale, A., Gimmillaro, M., and Polizzi, G. 2003. Prove triennali di lotta con mezzi chimici e biologici per il contenimento di Cylindrocladium pauciramosum in vivaio. Italus Hortus 10(S4):315-320. (In Italian).

67. Vitale, A., and Polizzi, G. 2007. First record of the perfect stage Calonectria pauciramosa on mastic tree in Italy. Plant Dis. 91:328.

68. Vitale, A., and Polizzi, G. 2008. First record of leaf spots and stem lesions on Pistacia lentiscus caused by Cylindrocladium pauciramosum and C. scoparium in Italy. Plant Pathol. 57:384.

69. Waipara, N. W., Di Menna, M. E., Cole, A. L. J., and Skipp, R. A. 1996 Pathogenicity of Cylindrocladium scoparium to pasture clover and grass species. Australas. Plant Pathol. 25:205-211. 